\title{
Hydrocarbons Migration through Groundwater Convergence toward Saline Depressions: A Case Study, Sidi El Hani Discharge Playa, Tunisian Sahel
}

\author{
Elhoucine Essefi, ${ }^{1,2}$ Mohamed Ali Tagorti, ${ }^{3,4}$ Jamel Touir, ${ }^{5}$ and Chokri Yaich ${ }^{1,2}$ \\ ${ }^{1}$ National Engineering School of Sfax, University of Sfax, Road of Soukra, km 4, 3038 Sfax, Tunisia \\ ${ }^{2} R U$ : Sedimentary Dynamics and Environment (DSE) (Code 03/UR/10-03), National Engineering School of Sfax, \\ University of Sfax, 3038 Sfax, Tunisia \\ ${ }^{3}$ Laboratory of Water Energy and Environment, National Engineering School of Sfax, University of Sfax, 3038 Sfax, Tunisia \\ ${ }^{4}$ Faculty of Sciences of Sfax, University of Sfax, Road of Soukra, km 4, 3038 Sfax, Tunisia \\ ${ }^{5}$ Higher Institute of Biotechnology of Monastir, Tahar Hadded Avenue, University of Monastir, Road Salem Bechir, BP n 56, \\ 5000 Monastir, Tunisia
}

Correspondence should be addressed to Elhoucine Essefi; hocinsefi@yahoo.fr

Received 30 May 2013; Accepted 31 July 2013

Academic Editors: W. K. Jo and Q. Zhou

Copyright (C) 2013 Elhoucine Essefi et al. This is an open access article distributed under the Creative Commons Attribution License, which permits unrestricted use, distribution, and reproduction in any medium, provided the original work is properly cited.

\begin{abstract}
This paper aims to provide proofs of hydrocarbons migration from petroleum reservoirs towards the surface of discharge playas. This is a case study of the discharge playa of Sidi El Hani, eastern Tunisia. The geochemistry of water of some hydrological drills in the Sahel area and of water from the discharge playa proves relatedness between the deep aquifer and the water of the discharge playa. Thus, the hydrology is now more than likely converging from the subsurface. This convergence may be an agent of transport of hydrocarbons. Concerning the organic matter within the discharge playa, high percentages of different fractions seem abnormal in such a saline context. This maturated organic matter should be viewed in the widest context of a multidisciplinary study taking into account the presence of petroleum potentials in the subsurface, the converging hydrogeology, and the tectonised region. The high percentage of Aromatic Polycyclic Hydrocarbon (APH) may be the result of hydrocarbons migration rather than anthropogenic pollution. As for the reinterpretation of previous works about the organic matter in playas done in sebkha Moknine, the contaminated organic matter, which was interpreted as a human induced activity, may have another origin from a reservoir located in the subsurface of the Sahel area.
\end{abstract}

\section{Introduction}

Since the study of the petroleum system alone is not enough to achieve a more precise exploration, petroleum migration has recently become an important duty for petroleum exploration and assessment in petroleum basins (e.g., [1]). Over the last decades, several authors [2-7] have presented convincing evidences showing the integration of geological, geophysical, geochemical, hydrodynamic, and geothermal data as a powerful tool for understanding the relationships between groundwater and oil movement in sedimentary basins. As for the Tunisian context, some studies (e.g., [5, 816]) have revealed significant correlations between aquifers hydrodynamics and major conventional petroleum accumulations. Nevertheless, to satisfy this combination between the hydrogeological approach and the petroleum exploration, it is necessary first to prove the existence of a petroleum potential. Subsequently, the mechanism of migration of hydrocarbons by groundwater convergence may be discussed according to the geological context of the region. Concerning the case of the Tunisian Sahel, previous studies proved that these two conditions are quite satisfied. On the one hand, numerous geological studies and seismic investigations of the Sahel area have greatly contributed to defining the regional and local geological framework, and thus to establishing the 
possible geometry and boundaries of potential reservoirs [1721]. These studies pinpointed additional leads for petroleum exploration, particularly in synclinal and graben structures such as the graben of Sidi El Hani. On the other hand, the groundwater convergence towards the surface of Sidi El Hani discharge playa has been recently proved [2225]. Consequently, this paper aims to provide proofs of hydrocarbons migration from a reservoir in the Sahel area. Nevertheless, it will not predict the age of the reservoir nor will it locate its geographical setting. In doing so, this paper will pinpoint the importance of the geochemical and hydrogeological studies in any petroleum exploration in Tunisia. It will also call into question some recent studies of the organic matter of sebkhas in the Sahel area (e.g., [2629]) that had never taken into account this possibility of hydrocarbons migration. Furthermore, it will reinterpret data recently published by Chairi et al. [29] about the organic content of the sebkha Moknine; such reinterpretation will take into account the geodynamic and hydrologic contexts enhancing the hydrocarbons migration.

\section{Geographical and Geological Settings}

2.1. Geographical Location of Sidi El Hani Discharge Playa. The sebkha of Sidi El Hani is a NW-SE lengthened depression in the Sahel area (eastern Tunisia) (Figure 1). It represents the basal part of the endorheic system Mechertat-Chrita-Sidi El Hani (Figure 1) [30]. Topographically, Sidi El Hani discharge playa is limited by various hills that barely reach more than $100 \mathrm{~m}$ of altitude (Figure 1). The basin of Sidi El Hani is an eastern diverticulum of the Kairouan plain, which penetrates toward a coastal folded upland. This topographic contrast helps create a developed hydrological network within the $3,300 \mathrm{~km}^{2}$ of its hydrological basin. The area of Sidi El Hani discharge playa is approximately $370 \mathrm{~km}^{2}$, and its average depth of water is $0.4 \mathrm{~m}$, but it can reach in some locations to $0.8 \mathrm{~m}$. The filling of the sebkha as such is made up of clay, silt, and sand. This filling is generally mixed with rich organic matter $[22,25]$. Such organic content may be either autochthonous produced within the playa or allochthonous migrating from the surface or the subsurface.

2.2. Geodynamic Context of the Tunisian Sahel and the Genesis of Sidi El Hani Discharge Playa. The Sahel domain in eastern Tunisia is separated from the Atlantic domain by the socalled north-south axis (e.g., [18]). At the surface, this domain appears less affected by few tectonised structures because its architecture is sealed by the Plio-Quaternary sediments [20]. However, in the subsurface, a geological complexity associated with triassic halokinesis along a major faults system and an intense volcanic activity essentially from aptian to late cretaceous was noticed [31]. Geophysical and geodynamic studies [17-21, 32], gave a lot of information about the deep structures in the Sahel area. These studies found out strong proofs for potential petroleum reservoir and for intensively tectonised subsurface allowing the hydrocarbons migration. Figure 2 gives a bird eyes sight on the Tunisian Sahel. It divides the Sahel domain into three major zones, which are separated by three major tectonic accidents.
On the other hand, gravimetric data prove an important subsidence associated with faulted zones would be guessed from the surface monotony and the deep structure of the domain [18]; gravimetric data analyses have also permitted the reconnaissance of the crustal and gravimetric setting of the northern part of the Sahel domain and the discussion of main outlines of subsurface structures. The deep structure of a particular zone (Kairouan-Sousse-Monastir area) demonstrates the existence of an EW thinning of the crust, metaphorically compared with glove finger [18]. This deep structuring is perfectly shown by the high-resolution second-order enhanced analytic signal technique developed to image geologic boundaries such as contacts and faults. The Bouguer gravity map of the northern part of the Sahel domain in Tunisia shows a complex gravity field essentially in the Kairouan-Sousse-Monastir area and neighboring regions. However, Gabtni [18] also noticed a particular crustal anomaly (Figure 3) in the Kairouan-Sousse-Monastir area. This anomaly was attributed to the existence of petroleum reservoir in this region.

It is worth noting also that some petroleum wells are located in the Sahel area, and they have been exploited since the 1980s. For instance, the field of Sidi Kilani is located south of Kairouan, (Figure 2). This field produces oil and very salty water $(155 \mathrm{~g} / \mathrm{L})$ from the strongly fractured carbonated series of the Campanian-Maastrichtian Abiod formation. Furthermore, this figure also shows the presence of a network of faults that may serve in facilitating the hydrocarbons migration and/or the connection between the subsurface and shallow aquifers [21, 24, 25, 33-39]. Accordingly, hydrocarbons do have the possibility to immigrate towards Sidi El Hani discharge playa (e.g., [1]) especially with the presence of well-defined hydrogeological conditions converging towards the surface of the discharge playa [22-24, 37].

As for the genesis of the discharge playa as such, the genesis and evolution of the coastal lagoons and sebkhas of the Tunisian eastern coast were controlled by two successive quaternary tectonic phases. A Postvillafranchian NW-SE compression was followed by a Tyrrhenian NE-SW extension [33]. These phases resulted in many populations of fracturing according to different orientations rising in various places of the Sahel. For instance, the villafranchian calcareous crust observed in folded edges of the present playas is also cut out into N 00-20 and N 90-110 rhombuses fractures with a set of dextral and senestral setbacks. These tectonic fractures resulted from the juxtaposition of the compressive and extensional structures during the Postvillafranchian compression and transpressional Tyrrhenian extension. The tectonic activity is still, until now, noticed by a continuous seismicity in the Sahel area [32]. Such seismic activities may be materialized by alignments of fault-springs of water in many locations within depressions [36] and may enhance the hydrocarbon traps to escape upward through reactivated faults and structural permeability (e.g., [40]).

2.3. Hydrogeological Context of the Sidi El Hani Discharge Playa. Figure 4 represents the hydrogeological model recently proposed by Essefi [22] and Essefi et al. [24] about 

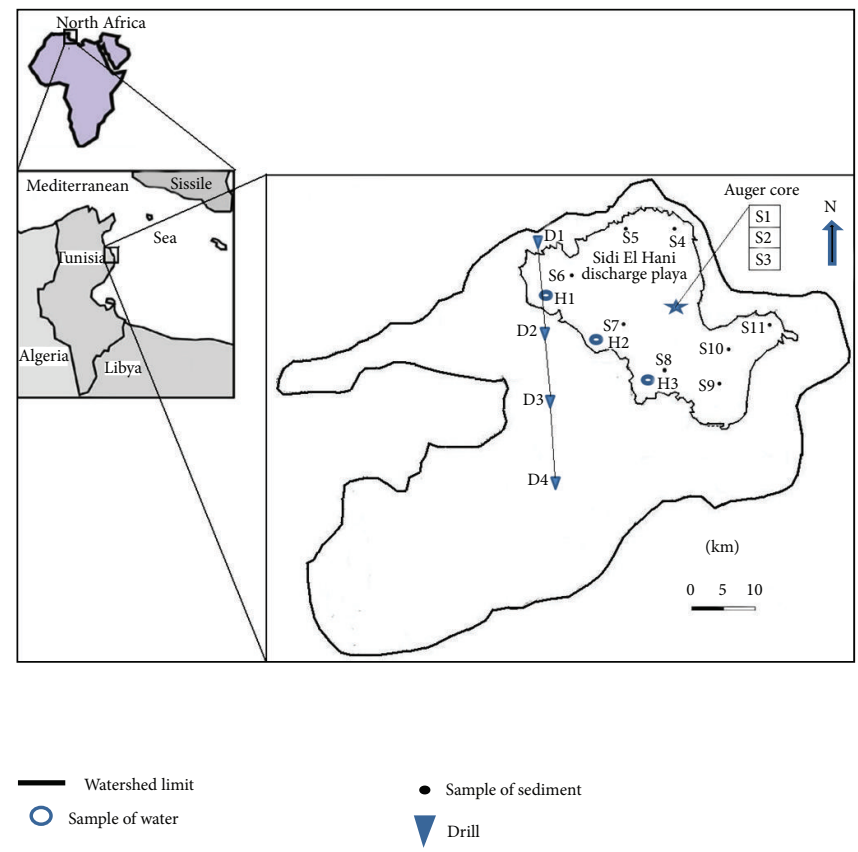

FIgUre 1: Geographical location of the Sidi El Hani discharge playa and samples locations.

the relation of Sidi El Hani saline environment with Kairouan aquifer. The Sidi El Hani saline environment is commanded by somewhere in deep domes of salt and/or salty water. On the other hand, due to this hydrogeological dominance, the climatic effect is limited [37-39]. The convergence of water towards the discharge playa may be also materialized by the appearance of springs of water in many locations $[22,25,30$, 35 ]. As for the petroleum side, the convergent aquifers may be the agent of transport of hydrocarbons from any potential reservoir (e.g., [11, 16]). Since it creates an underpressured zone allowing the oil to migrate upwards. According to the investigation of the geographical, geodynamic, and hydrogeological contexts of the Sahel area, it seems that Sidi El Hani discharge playa is more than likely to be contaminated by migrated hydrocarbons. Nevertheless, this hypothesis should be quite distinguished from the human-induced activity.

\section{Methods}

3.1. Geochemical Detection of the Groundwater Contribution. Four drills (Figure 1; D1, D2, D3, and D4) were verbally portrayed in terms of lithology, locations of aquifers, and grain size distribution. They were useful to investigate the shallow subsurface in the vicinity of Sidi El Hani discharge playa. Geochemical analyses of major cations and anions of water samples of three drills (Figure 1; D1, D3, and D4) were also recuperated. As for samples of water from the discharge playa, they are recuperated after coring. In this location, the aquifer is generally between 0.5 and $0.7 \mathrm{~m}$ below the surface (Figure 1; H1, H2, and H3). Major ions are detected by using ion liquid chromatography (ILC) equipped with columns ICPak TM CM/D for cations using EDTA and nitric acid as an eluent/solvent. Crude data of analyses of water of drills and samples from the discharge playa were taken to endure a geochemical study. First, the use of Piper diagram was meant to study the geochemical facies of samples. Second, the use of Schoeller-Berkalof diagram was meant to prove the geochemical relatedness between Sidi El Hani discharge playa and Kairouan aquifer.

3.2. Study of the Organic Matter. In our case, only hydrocarbons contained in the sediment were studied. One sample was obtained from the mixture of samples from different locations of the surface of the discharge playa (Figure 1; S4, S5, S6, S7, $\mathrm{S} 8, \mathrm{~S} 9, \mathrm{~S} 10$, and S11) and from the very shallow (1.5 $\mathrm{m}$ to $3 \mathrm{~m})$ subsurface (Figure 1; S1, S2, and S3). The quantitative and qualitative analyses of hydrocarbons proceeded in four stages: the elimination of elementary sulfur, the extraction of the organic matter, the purification, and eventually the detection of different components.

3.2.1. Desulphurization. The sample of sediment was first placed in the steamroom at $40^{\circ} \mathrm{C}$ to be dehydrated; then it was crushed manually by a mortar. Only the fraction that was smaller than $63 \mu \mathrm{m}$ was analyzed. Due to its high content in Sidi El Hani discharge playa [22], sulfur bothers the separation of the saturated and aromatic hydrocarbons. Thus, it should be fixed within a column on an amalgam of copper and zinc. Amalgam preparation consisted in (1) dissolving $200 \mathrm{mg}$ of crystallized sulfate of copper within 2 liters of distilled water under agitation, (2) dissolving $30 \mathrm{~g}$ of powder of zing within $50 \mathrm{~mL}$ of distilled water, and (3) shedding drop by drop the mixture of zinc within the solution of copper in order to avoid pulverizing of amalgam. The obtained pasty 


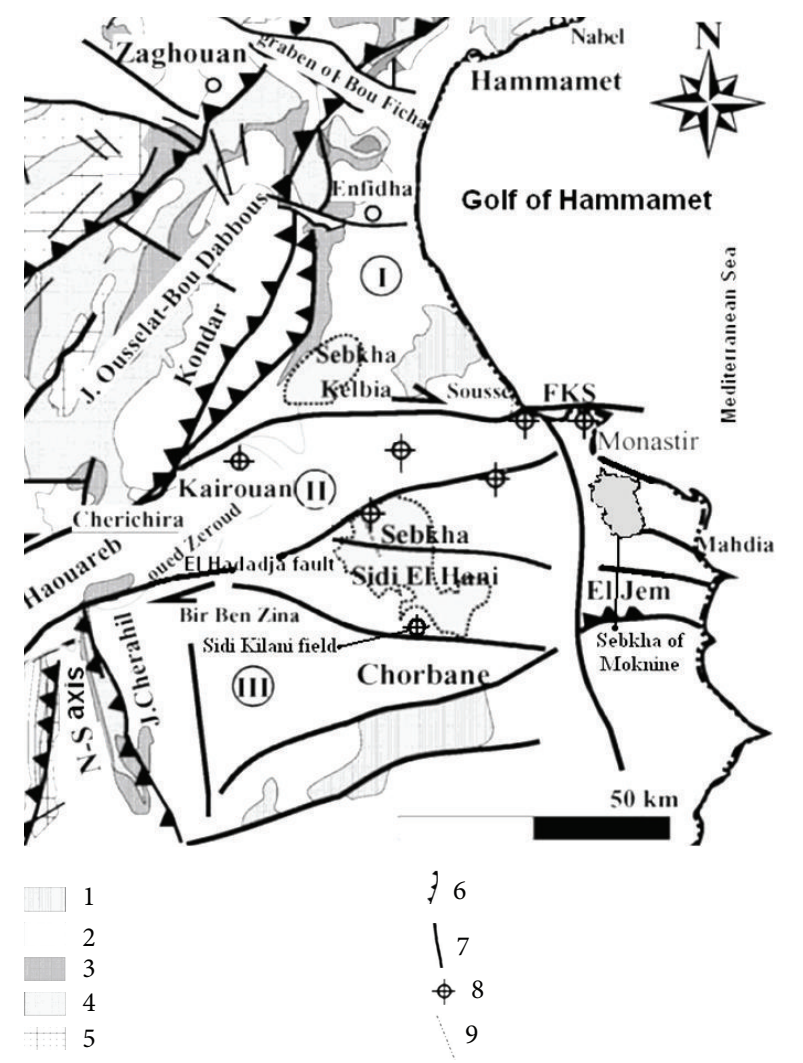

FIGURE 2: Tectonic summary map of northeastern Tunisia compiled from outcrop and subsurface data: 1, Mio-pliocene; 2, miocene; 3, oligocene; 4 , eocene; 5 , late cretaceous; 6 , thrust faults; 7 , major faults; 8, petroleum well; I, zone of Kelbia-Enfidha; II, zone of Kairouan-El Hdadja; III, zone of Sidi El Hani-Chorbane [20].

mixture with a cupric color permitted the fixation of the elementary sulfur. The operation of sulfur elimination was carried out on a glass column (Pasteur Pipette), having $10 \mathrm{~cm}$ of length and $5 \mathrm{~mm}$ of diameter. The column was washed many times with acetone in order to eliminate water; then it was rinsed with $\mathrm{CHCl}_{3}$. The sample was placed on the amalgam and washed many times with $\mathrm{CHCl}_{3}$. During this operation, the amalgam maintained the sulfur and became black. The desulfured extract was recuperated within a pipe with calibrated haemolysis in order to be weighted after total evaporation of the solvent.

3.2.2. Extraction of the Organic Matter. An amount of $10 \mathrm{~g}$ of the desulfured fine fraction was placed in a cellulose cartridge of a soxlet. The organic solvent was composed of $100 \mathrm{~mL}$ of methanol $(\mathrm{MeOH})$ and $200 \mathrm{~mL}$ of dichloromethane $\left(\mathrm{CH}_{2} \mathrm{Cl}_{2}\right)$ evaporate under the heat effect. Hence, it joined the cooling agent while passing by the tube supply main; thus, it condensed to fall within the cartridge of extraction. The sample of sediment macerated with organic solvent. Once the cartridge was full, the liquid accompanied by the extracted organic matter turned over in the balloon; the cycle continued making the balloon progressively enriched by the organic matter. It was necessary to count approximately 7 hours in

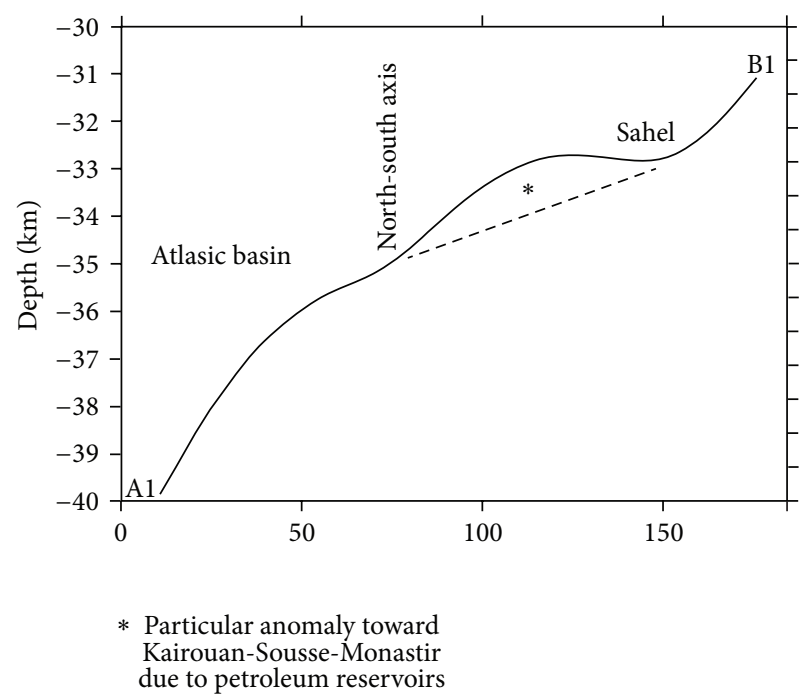

FIGURE 3: Gravimetric data localizing petroleum potentials in the Sahel area, Tunisia [18].

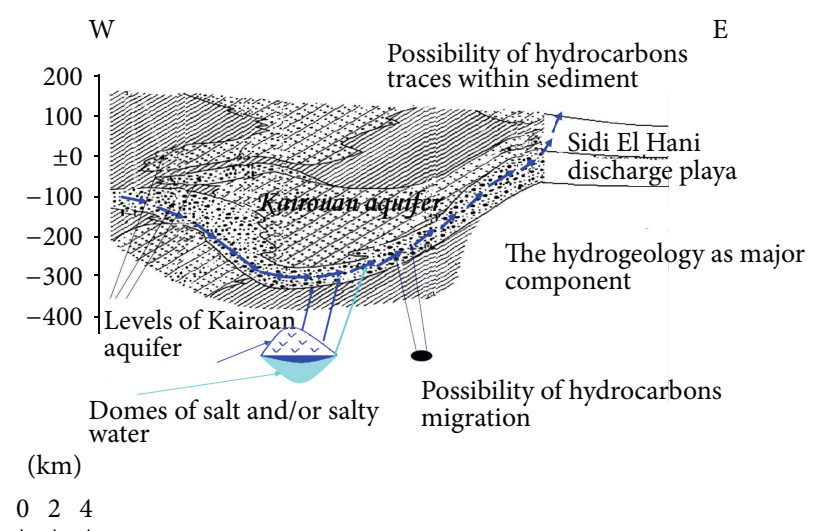

FIgURE 4: Convergence of Kairouan aquifer towards the surface of Sidi El Hani discharge playa and the possibility of hydrocarbons migration ([24]; modified and reinterpreted).

order to extract by this method all the organic matter of a sample. Thereafter, the balloon was placed in a Marie bath to evaporate solvent and recuperate the organic matter. Then, the concentration contained in a sample was obtained by weighing the dry residual.

3.2.3. Purification of Hydrocarbons. The purification of different components of hydrocarbons was done by fractionation. To be able to dose with precision only hydrocarbons, other components should be eliminated from the organic matter; the residual suspended with dichloromethane passed through a burette containing the florisil, which is a gel that can be crossed only by hydrocarbons and others negligible lipidic compounds. The total hydrocarbons were obtained after the passage in the burette. The concentration of these total hydrocarbons is determined also by weighting the dry residual obtained after evaporation. The amount of hydrocarbons in this sample was compared with data of Sidi Kilani 
S

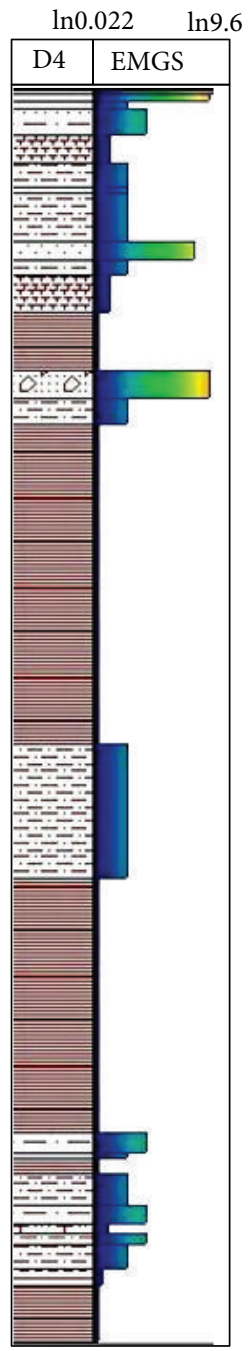

(km)
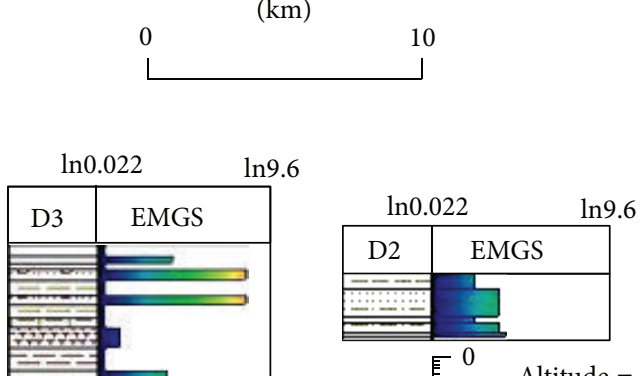

${ }_{-20}^{0}$ Altitude $=0$

ए

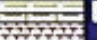

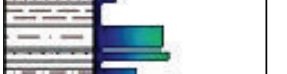

들

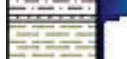

$==$

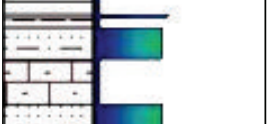
Fin
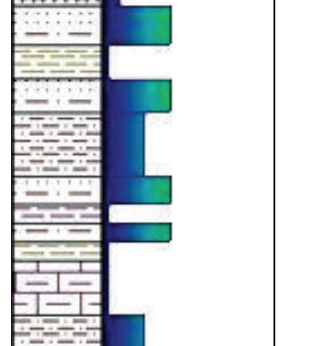

$+\div-7$

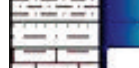

$=1-1-$

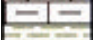

$=$

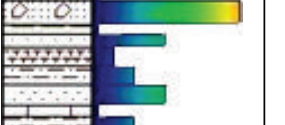

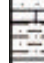

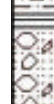

0

플
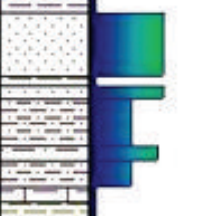

$\overline{-1}-\overline{7}$

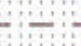

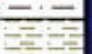

1

$-20$

$-40$

$-60$

$-80$

$-100$

$-120$

$-140$

$-160$

$-180$

$-200$

$-220$

$-240$

$-260$

$-280$

$-300$

$-320$

$-340$

$-360$

$-380$

$-400$

$-420$

$-440$

$-460$

$-480$

$-500$

$-520$

$-540$

$-560$

$-580$

$-600$

$-620$

$-640$

$-660$

$-680$

$-700$

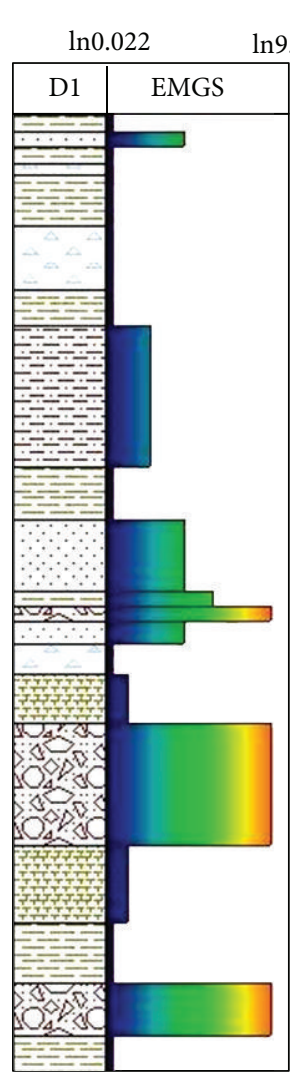

$-0$

$-20$

$-40$

$-80$

$-100$

$-120$

$-140$

$-160$

$-180$

$-200$

$-220$

$-240$

$-260$

$-280$

$-300$

$-320$

$-340$

$-360$

$-380$

$-400$

$-420$

$-440$

$-460$

$-480$

$-500$

$-520$

$-540$

$-560$

$-580$

$-600$

$-620$

$-640$

$-660$

$-680$

$-700$

$-720$

$-740$

$-760$

裳 -780

The EMGS is presented by the logarithm (e, base)

of the estimated medium grain size $(\mathrm{mm})$; it ranges

between $\ln 0.022=3.8$ and $\ln 9.6=2.26$

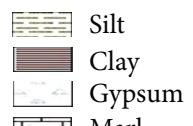

푸리 Marl

FIGURE 5: Correlation between four drills showing the evolution of the shallow subsurface in the vicinity of Sidi El Hani discharge playa. 


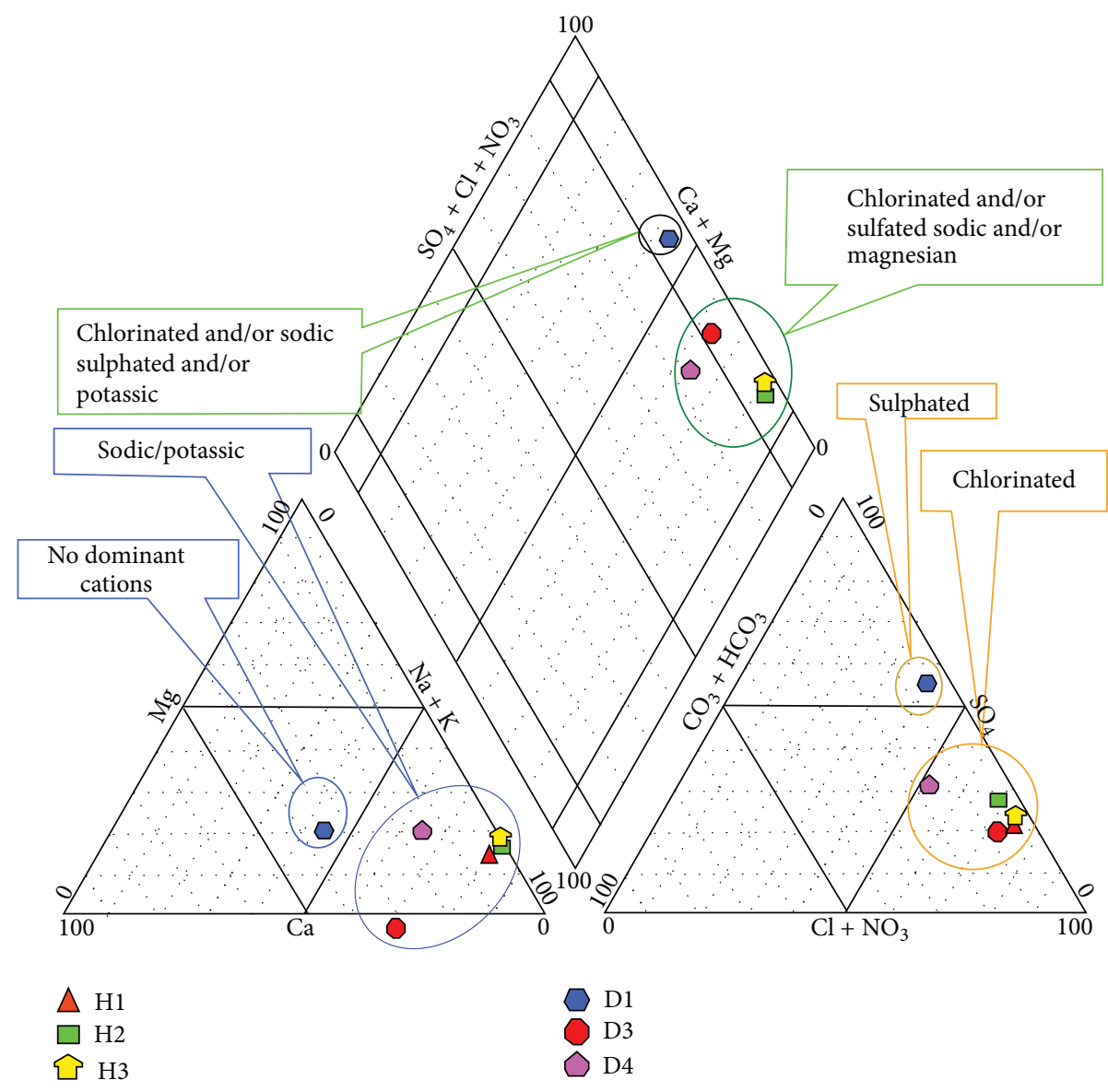

FIGURE 6: Piper diagram of samples of water from the aquifer of Kairouan and Sidi El Hani discharge playa.

field recently published by Boussiga et al. [41]. To facilitate the detection of hydrocarbons by chromatography, the saturated are separated from nonpolar compounds. The total residual hydrocarbon was included in hexane then passed in a silica gel column; the fraction saturated with hydrocarbons may be recovered. In the same silica column nonpolar hydrocarbons were fairly elected by a hexane dichloromethane mixture with the proportions of $2 / 3-1 / 3$. This recovered fraction corresponds to polycyclic aromatic hydrocarbons. The percentage of the polar fraction may be obtained by simple subtraction of alkanes and aromatic polycyclic hydrocarbons from total hydrocarbons.

3.2.4. Detection of Hydrocarbons by Chromatography. The detection of hydrocarbons of the saturated fraction was carried out by gas chromatography (GC) coupled with mass spectroscopy (MS). Thus, these aliphatic hydrocarbons were analyzed by gas chromatography-mass spectrometry HP 6890-HP 5973 MSD combination (Agilent Technologies, Wilmington, DE, USA). The GC was used with a $30 \mathrm{~m}$ fusedsilica column $(0.25 \mathrm{~mm}$ i.d.) coated with $5 \%$ phenyl methyl siloxane. Helium was used as the carrier gas at a flow rate of $1.4 \mathrm{~mL} / \mathrm{min}$. The temperature program was as follows: temperature held at $40^{\circ} \mathrm{C}$ for $1 \mathrm{~min}$, then increased from 40 to $120^{\circ} \mathrm{C}$ at $30^{\circ} \mathrm{C} \mathrm{min}^{-1}, 120$ to $300^{\circ} \mathrm{C}$ at $5^{\circ} \mathrm{C} \mathrm{min}^{-1}$ with the final isothermal hold at $300^{\circ} \mathrm{C}$ for $20 \mathrm{~min}$. The mass spectrometer operated in the electron impact (EI) mode at $70 \mathrm{eV}$ (ionization energy) and scanned from 50 to 650 Dalton. Compounds were identified by comparison with published mass spectra and relative retention times.

3.3. Detection of Chemical Elements. At the level of Sidi El Hani discharge playa, samples of sediment were taken from the subsurface (from $150 \mathrm{~cm}$ to $300 \mathrm{~cm}$ ) (Figure 1, S1, S2, and S3) by an auger and the surface (Figure 1; S4, S5, S6, S7, S8, S9, S10, and S11). The metallic content of these samples was compared with data of Sidi Kilani field recently published by Boussiga et al. [41]. The analysis of heavy metals was made on the level fine fraction of the sediments lower than $63 \mu \mathrm{m}$. It is generally recognized that this fraction concentrates the highest values of trace elements [42]. The samples were dried with dry $40^{\circ} \mathrm{C}$ and were filtered. The fraction lower than $60 \mu \mathrm{m}$ was analyzed by Plasma Torch (PT).

\section{Results}

4.1. Hydrogeology and Water Geochemistry of Sidi El Hani Discharge Playa. As it is shown in Figure 5, N-S correlation between four hydrogeological drills was done to investigate the shallow subsurface in the vicinity Sidi El Hani discharge 


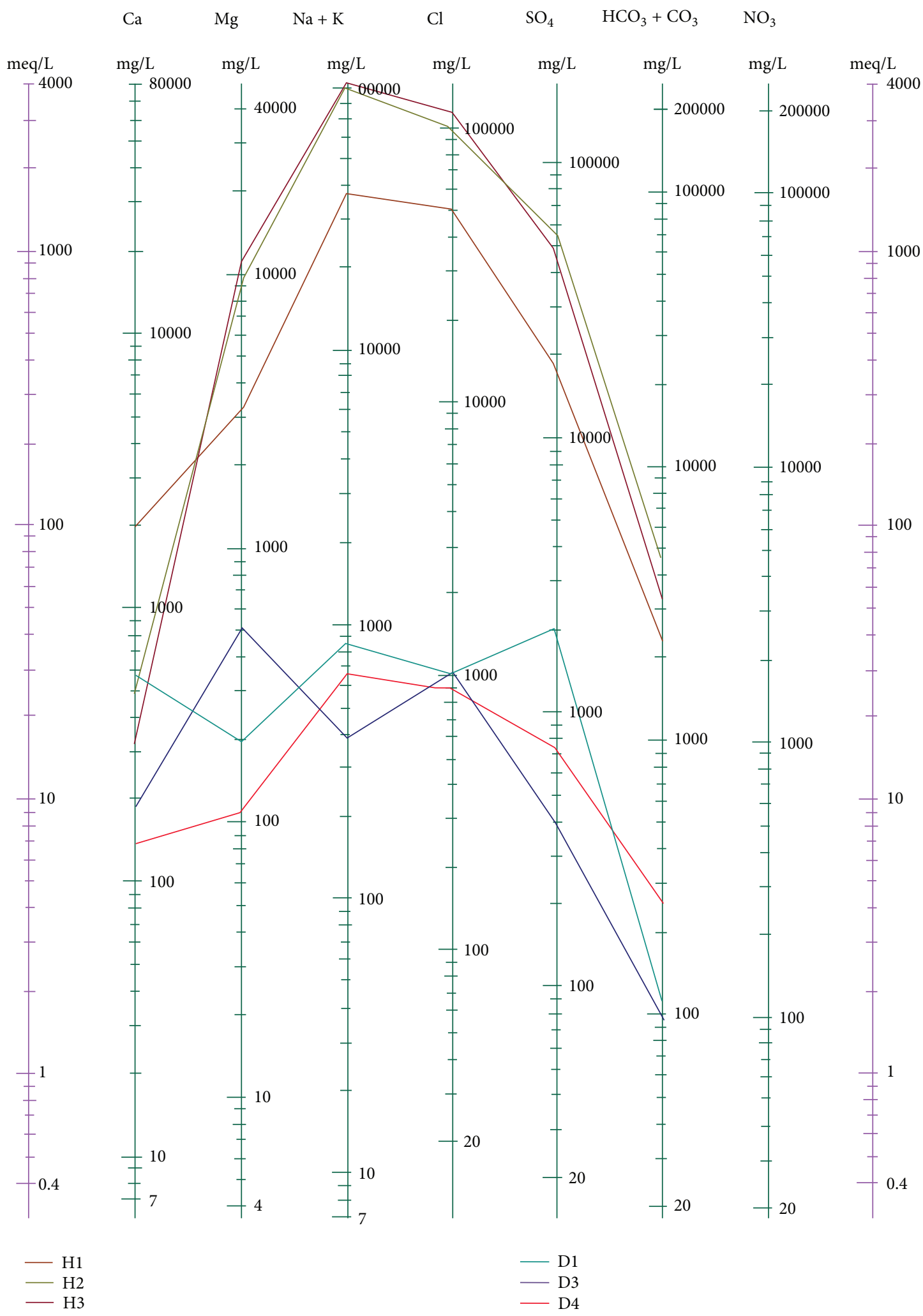

Figure 7: Schoeller-Berkalof diagram of samples of water from the aquifer of Kairouan and Sidi El Hani discharge playa showing their geochemical relatedness. 


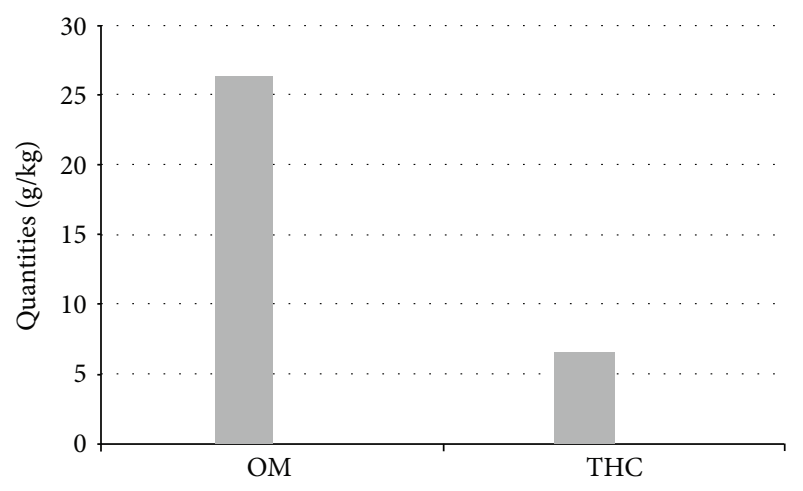

FIGURE 8: Concentrations of the organic matter (OM) and total hydrocarbons (THC) in the mixed sample of sediment from Sidi El Hani discharge playa.

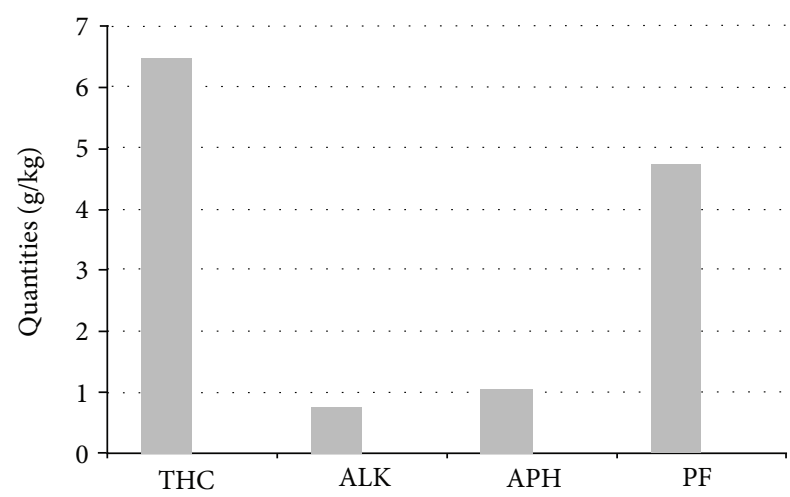

Figure 9: Concentrations of the total hydrocarbons (THC), polar fraction (PF), alkane (ALK), and aromatic polycyclic hydrocarbons $(\mathrm{APH})$ in the mixed sample of sediment from Sidi El Hani discharge playa.

playa. It is worth noting that aquifers are found in gravely layers [22], facilitating the hydrocarbons migration [1]. Furthermore, this silico-clastic series shows a considerable variability in terms of sediment thickness, which is another sign of a tectonised region. This thick series is also a strong sign of high subsidence (Figure 5, D3); such a subsidence should increase the maturity of the organic matter in the subsurface of the Sahel area.

4.1.1. Piper Diagram. Concerning Piper diagram (Figure 6), the interpretation of the dispersion of different samples within the lozenge of anions and cations, the diagram of anions and the diagram of cations may give an idea of the geochemical facies. On the lozenge, two families of samples are distinguished. First, the majority of samples make up the chlorinated and/or sodic sulphated and/or potassic family; such relatedness between the geochemistry of drills in vicinity of the discharge playa, and its water is a strong proof that Kairouan aquifer feeds the discharge playa according to the proposed model of Essefi [22]. Second, D1 represents the chlorinated and/or sodic sulphated and/or magnesian family. This geochemical facies is more than likely influenced by the

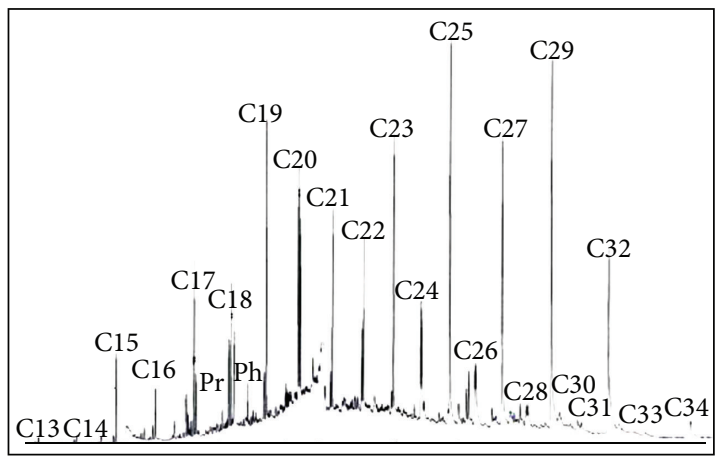

FIGURE 10: Chromatogram of saturated hydrocarbons in the mixed sample of sediment from Sidi El Hani discharge playa.

gypsum layer located between $46 \mathrm{~m}$ and $82 \mathrm{~m}$ in D1 (Figure 5, D1). Nevertheless, the geochemistry of this second family may be explained by the geodynamic context; D1 is located near the Triassic dome in the subsurface of Zarmdine [17]. In general, the majority of drills have the same facies, which is mainly made up of water charged with $\mathrm{Na}^{+}$and $\mathrm{Cl}^{-}$. This geochemical facies suggest that this aquifer is more than likely leaching layers of halite, which may be Triassic [17] and/or Messinian [22] or is made up of salty paleo-water probably inherited from the Messinian Salinity Crisis [22].

4.1.2. Schoeller-Berkalof Diagram. In such a diagram, similarity between samples generally appears in spite of the different concentrations. Thus, samples having genetic relationship are presented by parallel lines. As for the studied samples, they present for the most an evident similarity (Figure 7). Families previously distinguished are also seen in this diagram. The $\mathrm{F} 1$ is characterized by high value of $\mathrm{Na}^{+}$and $\mathrm{Cl}^{-}$. The F2 is characterised by high values of $\mathrm{SO}_{4}{ }^{-}$. Being subparallel lines representing different samples show that there is relatedness between water of Sidi El Hani discharge playa (Figure 7; H1, H2, and H3) and Kairouan aquifer (Figure 2; D1, D4, and D3).

\subsection{Geochemistry of the Organic Matter}

4.2.1. Quantitative Analyses of Various Fractions. The elimination of the elementary sulphur shows that the sample form Sidi El Hani discharge playa is rich in sulphur $(5 \mathrm{~g} / \mathrm{kg})$. This strong presence may be explained by the activity of anaerobic bacteria in a reduced environment, as it may be explained by sulphur migration from a petroleum reservoir. This high amount of sulphur is noticed in many saline environments such as the sebkha of Moknine (e.g., [2628]). It is also detected in Sidi Kilani petroleum field [41]. After weighting the dry residues, the different fractions are obtained. Figure 8 shows the relative percentages of organic matter (OM) and total hydrocarbons (THC). Comparably to results of the organic matter in sebkha of Moknine (e.g., [29]), these amounts are relatively high and may have an allochthonous origin. 


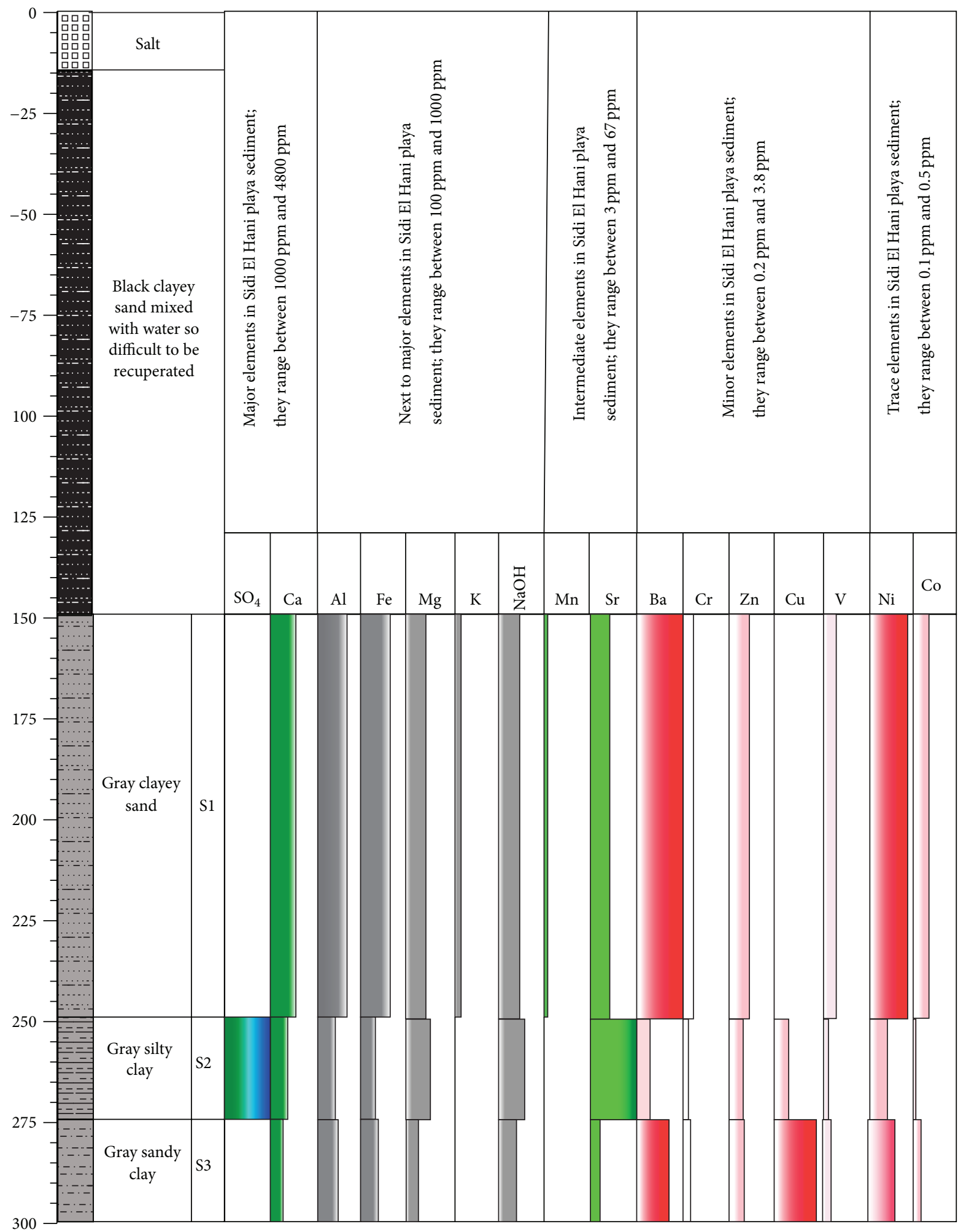

FIGURE 11: Evolution of the amounts of chemical elements along an auger drill in Sidi El Hani discharge playa.

On the other hand, Figure 9 shows the distribution of different components of the total hydrocarbons such as alkanes (ALK) aromatic polycyclic hydrocarbons (APHs) and polar fraction $(\mathrm{PF})$. The predominance of the polar fraction
(75\%) indicates a primarily biological origin of hydrocarbons. Nevertheless, the presence of relatively high amount of APHs (15\%) represents actually a geochemical anomaly in such environments. The hydrocarbons, thus, have a double 
TABLE 1: Concentrations chemical elements (ppm) of different sediment samples from Sidi El Hani discharge playa.

\begin{tabular}{lcccccccccccccccc}
\hline Samples & $\mathrm{Al}$ & $\mathrm{Ca}$ & $\mathrm{Fe}$ & $\mathrm{Mg}$ & $\mathrm{SO}_{4}$ & $\mathrm{~V}$ & $\mathrm{Zn}$ & $\mathrm{Ba}$ & $\mathrm{Co}$ & $\mathrm{Cr}$ & $\mathrm{Cu}$ & $\mathrm{K}$ & $\mathrm{Mn}$ & $\mathrm{Ni}$ & $\mathrm{Sr}$ & $\mathrm{NaOH}$ \\
\hline S1 & 737 & 2937 & 684 & 432 & 850 & 1.18 & 1.85 & 3.79 & 0.25 & 1.04 & 0.3 & 179 & 9.12 & 0.46 & 29 & 516 \\
S2 & 448 & 2206 & 351 & 526 & 4750 & 0.62 & 1.36 & 1.2 & 0.14 & 0.6 & 1.2 & 102 & 3.26 & 0.27 & 66 & 591 \\
S3 & 541 & 1715 & 425 & 316 & 228 & 0.85 & 1.44 & 2.67 & 0.18 & 0.84 & 3.3 & 124 & 5.43 & 0.33 & 17 & 409 \\
S4 & 514 & 2150 & 560 & 400 & 570 & 1.4 & 1.6 & 3.5 & 0.2 & 1.1 & 0.8 & 138 & 4.2 & 0.5 & 32 & 569 \\
S5 & 812 & 2050 & 640 & 520 & 840 & 0.9 & 1.7 & 1.8 & 0.42 & 0.6 & 2.7 & 146 & 4.9 & 0.36 & 49 & 490 \\
S6 & 753 & 1960 & 570 & 490 & 790 & 1.1 & 1.6 & 1.6 & 0.7 & 0.4 & 3.2 & 198 & 5.6 & 0.65 & 58 & 567 \\
S7 & 492 & 1650 & 580 & 380 & 860 & 1.3 & 1.2 & 2.9 & 0.9 & 1.2 & 2.2 & 173 & 5.3 & 0.25 & 47 & 612 \\
S8 & 613 & 1960 & 379 & 420 & 690 & 1.6 & 2.2 & 2.6 & 0.1 & 0.9 & 0.9 & 142 & 5.7 & 0.4 & 45 & 480 \\
S9 & 759 & 2140 & 460 & 510 & 760 & 2.1 & 2.4 & 3.1 & 0.13 & 0.7 & 1.5 & 156 & 3.9 & 0.6 & 38 & 561 \\
S10 & 548 & 2640 & 510 & 380 & 890 & 1.6 & 1.8 & 2.2 & 0.8 & 0.65 & 2.9 & 215 & 4.7 & 0.45 & 60 & 523 \\
S11 & 623 & 2750 & 590 & 470 & 760 & 1.5 & 1.5 & 2.7 & 0.35 & 0.45 & 1.8 & 167 & 3.9 & 0.56 & 69 & 486 \\
\hline
\end{tabular}

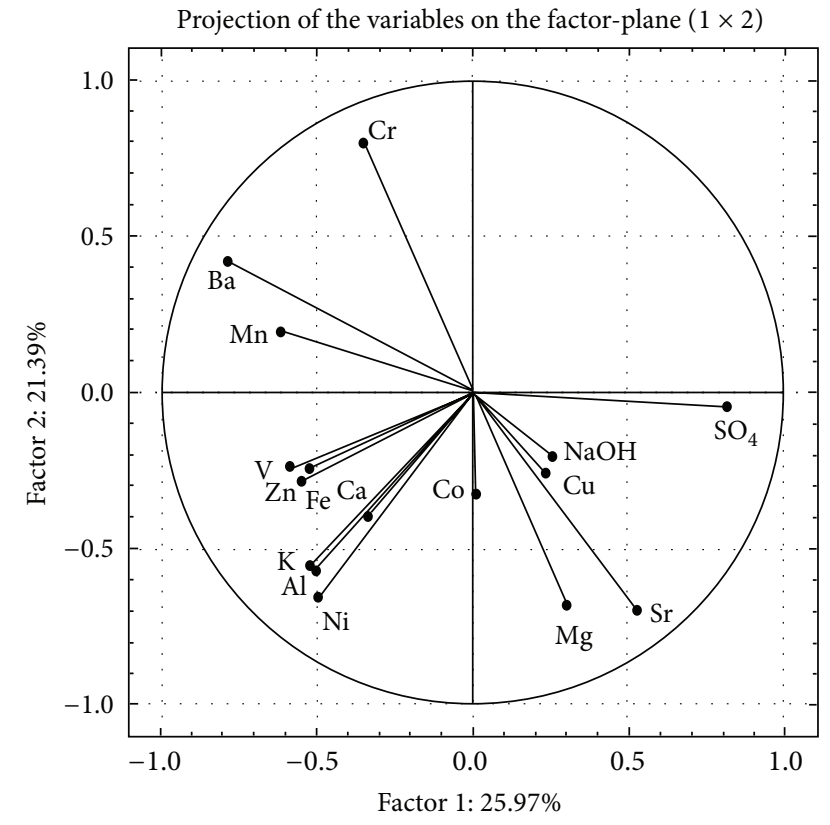

FIGURE 12: Principal component analysis of chemical elements of different sediment samples from Sidi El Hani discharge playa.

origin; though the principal origin remains biological and autochthonous, the allochthonous origin is more than likely to have a considerable contribution. Added to the hypothesis of a human induced pollution previously advocated by Chairi et al. [29] in sebkha Moknine, the hypothesis of migrating hydrocarbons could by no means be excluded in this region especially with the presence of many factors enhancing such a phenomenon.

4.2.2. Interpretation of the Chromatogram. The chromatogram of saturated hydrocarbons (Figure 10) may be divided in two parts. First, alkanes with low molecular weight range from C13 to C20. Second, alkanes with strong molecular weight range between $\mathrm{C} 21$ to $\mathrm{C} 31$. The absence alkanes with short chain ( $\mathrm{C} 1$ to $\mathrm{C} 10)$ on the chromatogram may be explained by their volatile aspect. The bimodal distribution

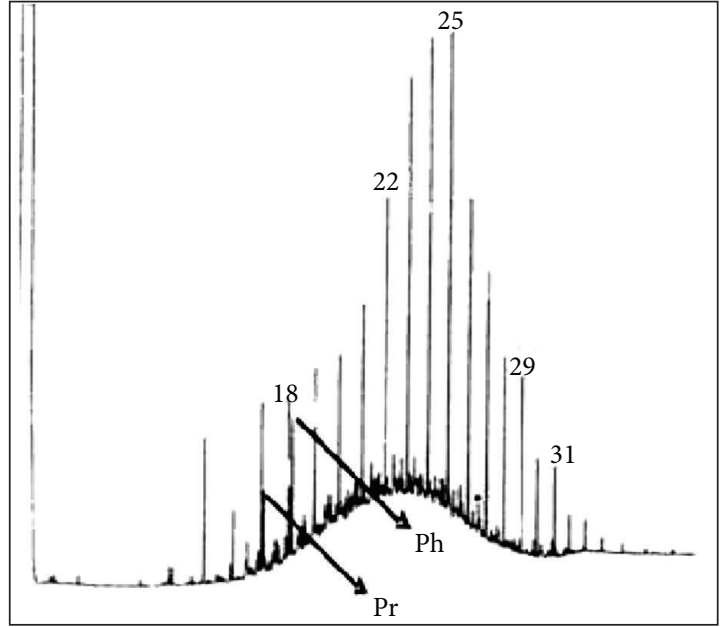

FIGURE 13: Chromatogram of saturated hydrocarbons in a sample of sediment from sebkha Moknine ([29]; reinterpreted).

is also noticed. The first mode is characterized by a predominance of $\mathrm{C} 15, \mathrm{C} 17$, and $\mathrm{C} 1$ alkanes. This disparity is characteristic of an algal origin; the hydrocarbons would have been formed after the maturation of the organic matter rejected by the algae. These short n-alkanes are generally attributed to autochthonous origin, since they are ubiquitously observed in aquatic organisms, such as bacteria and algae [43]. This specific distribution of n-alkanes has previously been attributed to bacterial or algal origin in similar contexts [44-47]. The second mode includes alkanes with strong molecular weight; it is also characterized by a predominance of alkanes made up of odd carbon atom. This disparity testifies a continental natural origin of hydrocarbons. They result primarily from the remains of plants. These long chain n-alkanes indicate a higher plant input since these compounds are abundant in epicuticular waxes of vascular plants [48]. It is worth noting that C21 and C23 prove an allochthonous origin [28]. The pristane and the phytane are products of the diagenesis of chlorophyll. The pristine corresponds to the evolution of chlorophyll in a reduced environment and the phytane in an oxidized environment. These two products appear on the 
TABLE 2: Coefficient of correlations of chemical elements with the first two factors of the principal component analysis.

\begin{tabular}{lcc}
\hline & Factor 1 & Factor 2 \\
\hline $\mathrm{Al}$ & -0.513660 & -0.568188 \\
$\mathrm{Ca}$ & -0.339586 & -0.395070 \\
$\mathrm{Fe}$ & -0.552638 & -0.280840 \\
$\mathrm{Mg}$ & 0.299645 & -0.675830 \\
$\mathrm{SO}_{4}$ & 0.810643 & -0.043908 \\
$\mathrm{~V}$ & -0.593311 & -0.245553 \\
$\mathrm{Zn}$ & -0.526560 & -0.241687 \\
$\mathrm{Ba}$ & -0.809000 & 0.425156 \\
$\mathrm{Co}$ & 0.005683 & -0.322803 \\
$\mathrm{Cr}$ & -0.355922 & 0.800061 \\
$\mathrm{Cu}$ & 0.227554 & -0.253303 \\
$\mathrm{~K}$ & -0.520373 & -0.550914 \\
$\mathrm{Mn}$ & -0.636364 & 0.195458 \\
$\mathrm{Ni}$ & -0.497073 & -0.656034 \\
$\mathrm{Sr}$ & 0.524855 & -0.697106 \\
$\mathrm{NaOH}$ & 0.250498 & -0.201187 \\
\hline
\end{tabular}

TABLE 3: $[\mathrm{Zn}] /[\mathrm{Fe}]$ ratio of different sediment samples from Sidi El Hani discharge playa and Sidi Kilani petroleum field.

\begin{tabular}{lc}
\hline Location & {$[\mathrm{Zn}] /[\mathrm{Fe}]$} \\
\hline Sidi Kilani & 0.0047 \\
S1 & 0.0027 \\
S2 & 0.0038 \\
S3 & 0.0033 \\
S4 & 0.0028 \\
S5 & 0.0026 \\
S6 & 0.0028 \\
S7 & 0.0020 \\
S8 & 0.0058 \\
S9 & 0.0052 \\
S10 & 0.0035 \\
S11 & 0.0025 \\
\hline
\end{tabular}

chromatograms; the ratio of pristan and phytane can thus inform us on the conditions of oxidation and reduction of the environment. In the studied case, without calculation one notes that this ratio is lower than 1 , it thus states that the hydrocarbons develop in a reduced environment.

4.3. Chemical Elements in Sediment. From the surface downward, the investigation of heavy metals and other chemical elements (Table 1; Figure 11) shows that amounts of these component are in the range of standards of such environments (e.g., [49]). Moreover, the variation of amounts does not follow a downward decreasing tendency. Such assumption proves that the human activity is less than likely to have caused these slight amounts. As for the horizontal distribution, values also show that components are in the range of acceptable (Table 1).

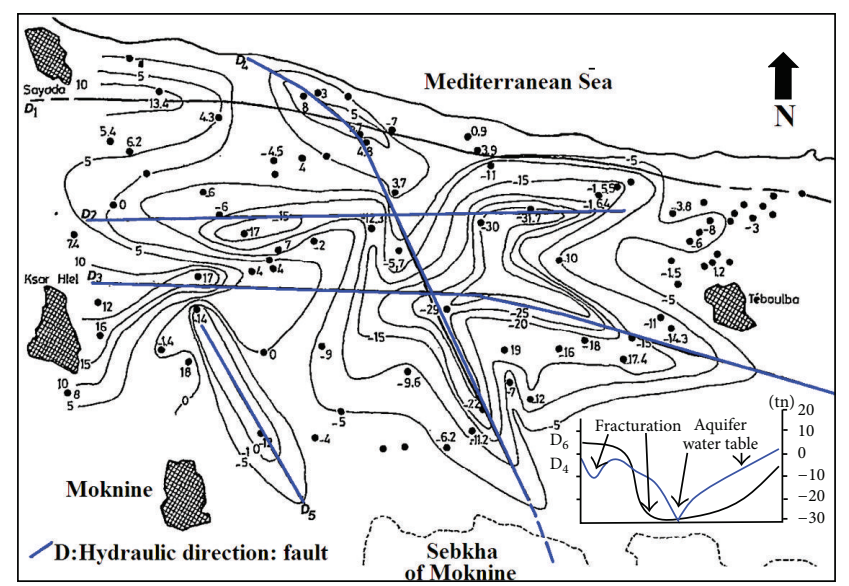

FIGURE 14: Hydrogeological map of Moknine region and the effect of the tectonic structures on the shape of the aquifer ([33]; reinterpreted).

They are in some extend correlated with aluminum evolution (Table 2; Figure 12). Thus, they are in the range of standards of clean saline environments (e.g., [49]). On the other hand, amounts of elements are comparable with data of Sidi Kilani field recently published by Boussiga et al. [41].

For instance, water recuperated from this field is particularly enriched with zinc $(\mathrm{Zn})(0.03 \mathrm{mg} / \mathrm{L})$, lead $(\mathrm{Pb})(0.1 \mathrm{mg} / \mathrm{L})$, manganese $(\mathrm{Mn})(0.46 \mathrm{mg} / \mathrm{L})$, iron $(\mathrm{Fe})$ $(6.28 \mathrm{mg} / \mathrm{L})$, and barium $(\mathrm{Ba})(1.3 \mathrm{mg} / \mathrm{L})$. The concentrations of these metals largely exceed the national standards in force and thus constitute a significant polluting content. Nevertheless, once migrated towards the surface of the discharge playa, these components become diluted and represent no environmental threat. But the proportionality between the amounts of different components maintains the traces of the migrating fluid. Table 3 represents the ratio between the amount of $\mathrm{Zn}$ and Fe in Sidi Kilani field and different locations in Sidi El Hani discharge playa. According to this ratio, the chemical content in both sites seems analogous. The more similar sites (S8, S9, and S10) are located in the side neighboring Sidi Kilani field. Such results further reinforce the idea of migrating hydrocarbons from a petroleum reservoir towards the surface of the discharge playa.

\section{Discussion}

This geochemical exploration of Sidi El Hani discharge playa and its watershed found out favorable conditions for the migration of hydrocarbons. Added to previous geophysical studies of the Tunisian Sahel area, which discuss the possibility of the existence of a potential petroleum reservoir located somewhere in the Sahel subsurface, the geochemistry of water of some hydrological drills in the Sahel area and of water of the discharge proves relatedness between them. Thus, the hydrology is now converging from the subsurface. This convergence may be the agent of transport of hydrocarbons. Concerning the organic matter, high percentages of different fractions seem abnormal in 
such a saline context. But this maturated organic matter should be viewed in a widest context of a multidisciplinary study. Because the high percentage of aromatic polycyclic hydrocarbon $(\mathrm{APH})$ may be the result of a hydrocarbons migration rather than anthropogenic pollution because in these areas the polluting human induced activity is next to absent. On the other hand, hydrocarbons migration toward such a discharge playa necessitates the coexistence of many conditions at the same time. First, the presence of an actual petroleum reservoir in the vicinity of the discharge playa; second, a fractured zone in order to facilitate the mobility of hydrocarbons, and third, a convergent aquifer toward the discharge playa to unsure the transport of hydrocarbons. These very conditions are verified in the case of Sidi El Hani discharge playa. First, the gravimetric data suggest the possibility of a hydrocarbon reservoir located in evaporitic domes in the vicinity of Sidi El Hani discharge playa [18]. Second, the tectonic activity, namely, the faulted structures $[17,19,20,33]$ may facilitate the hydrocarbons escapement. Third, this study proved that the surrounding aquifers are converging towards the discharge playa of Sidi El Hani and also proved the presence of a maturated organic matter. Moreover, to make a sharp distinction between the natural phenomenon of hydrocarbons migration and the human induced, this study investigated the geochemical content in terms of heavy metals and other components in order to show that this hydrocarbon contamination is far from having an anthropic origin. Rather, compared with the heavy metals content of Sidi Kilani field, the metallic content in Sidi El Hani discharge playa shows a kind of similarity with this neighboring petroleum field. Such assumption reinforces the hypothesis of hydrocarbons migration. As for previous works about the organic matter in playas of the Tunisian Sahel area, attempts recently done in sebkha Moknine [26-29] neglected the possibility of hydrocarbon migration. On the basis of the same technique (GC) (Figure 13), a maturated organic matter was found out at the surface and the shallow subsurface of the sebkha. In these works, the maturated organic matter has been interpreted as a human induced activity.

But it is worth noting that Amari and Bedir [33] discussed the relation between Moknine aquifer and the tectonic fracturing in the region. They found out that levels of Moknine aquifer are oriented towards privileged orientations mainly commended by faults orientations (Figure 14). Thus, the surface and the subsurface in this region are connecting with each other. Consequently, the contaminated organic matter interpreted as a human induced activity may have another origin from a reservoir located in the vicinity of the sebkha. This hypothesis seems more acceptable than human polluting activities because these saline environments are located isolated from any urbanization [30].

\section{Conclusion}

This study based on a geochemical exploration of water, organic matter, and heavy metals allowed the investigation of hydrocarbons migration towards Sidi El Hani discharge playa. Such migration is enhanced by a very particular geological framework characterized by the presence of a petroleum potential in the Sahel area providing with migrating hydrocarbons, a subsurface tectonised facilitating the migration through faults and fractures and aquifers converging toward the surface of the discharge playa behaving as agent of transport. In doing so, this study highlights the multidisciplinary approach in petroleum exploration. Moreover, it shows how this approach saves researchers from the misinterpretation of the high content of a contaminateed organic matter.

\section{References}

[1] D. Chen, X. Pang, K. Liu, J. Zhang, and R. Zhang, "Experimental investigation of secondary oil migration along subtle pathways: a mechanism for hydrocarbon accumulation in lenticular basinal turbidite reservoirs," Journal of Geochemical Exploration, vol. 101, no. 24, 2009.

[2] S. Neglia, "Migration of fluids in sedimentary basins," American Association of Petroleum Geologists Bulletin, vol. 63, no. 4, pp. 573-597, 1979.

[3] J. Toth, "Cross-formational gravity flow of groundwater: a mechanism of transport and accumulation of petroleum," The AAPG Studies in Geology, vol. 10, pp. 121-167, 1980.

[4] W. Bishop, "Petroleum geology of East-Central Tunisia," AAPG Bulletin, vol. 72, pp. 1033-1058, 1988.

[5] S. Bouri, Hydrothermie de surface et potentialités hydrothermales du Nord Tunisien-Identification des principales unités hydrogéothermiques. [Thèse de 3ème Cycle], Ecole Nationale d'Ingénieurs de Sfax, Université de Sfax, Sfax, Tunisia, 1994.

[6] N. R. Anderson, H. Wei, M. A. Hobart, and C. R. Wilkinson, "Active fluid flow in the Engerie Island area, offshore louisiana," Geophysics, vol. 10, pp. 12-17, 1991.

[7] J. W. Schmoker and T. R. Klett, "U.S. Geological survey assessment concepts for conventional petroleum accumulations," in Petroleum Systems and Geologic Assessment of Oil and Gas in the Southwestern Yoming Province, WYoming, Colorado, and Utah. USGS, Southwestern WYoming Province Assessment Team, U.S. Geological Survey Digital Data Series DDS-69-D U.S., Version 1, Chapter 19, U.S. Geological Survey, Denver, Colo, USA, 2005.

[8] H. Kouas and H. Ben Dhia, "Hdrogéologie pétrolière en Tunisie Centrale: réservoirs du Serdj, Abiod et El Garia," in 2ème Congrès National des Sciences de la Terre, p. 13, Tunis, Tunisia, September 1990.

[9] I. Yangui, A. Ben Gacha, H. Kouas, and H. Ben Dhia, "Hydrodynamisme et accumulations d'hydrocarbures en Tunisie Centrale," Rev. Tun. Energie, vol. 1, pp. 15-23, 1990.

[10] H. Ben Dhia and M. N. Meddeb, "Thermal regime and hydrodynamics in Tunisia and Algeria," Geophysics, vol. 56, pp. 10931102, 1991.

[11] H. Ben Dhia, F. W. Jones, M. N. Meddeb, and S. Bouri, "Shallow geothermal studies in Tunisia: comparison with deep subsurface information," Geothermics, vol. 21, pp. 503-517, 1992.

[12] S. Bouri, A. L. Mimi, R. B. Akhy, S. Tajina, F. Bellouti, and H. Ben Dhia, "Les potentialités hydrogéothermiques de la Tunisie Centre-Nord," Africa Geoscience Review, vol. 5, pp. 339-355, 1998.

[13] S. Bouri, M. Gasmi, Y. Zarhloule, A. Limayem, and H. Ben Dhia, “Traitement intégré des données de température: outil pour la recherche des hydrocarbures," Africa Geoscience Review, vol. 10, pp. 259-265, 2003. 
[14] I. Ben Abdallah, Etude du potentiel hydrogéothermal du Cap Bon: Traitement intégré des données de surface et de subsurface [M.S. thesis], Ecole Nationale d'Ingénieurs de Sfax (ENIS), Université de Sfax, Sfax, Tunisia, 2004.

[15] A. Limayem, Modélisation de bassins sédimentaires pour l'évaluation du potentiel pétrolier: Application au Golfe de Hammamet [Ph.D. thesis], Ecole Nationale d'Ingénieurs de Sfax (ENIS), Université de Sfax, Sfax, Tunisia, 2004.

[16] S. Bouri, M. Gasmi, M. Jaouadi, I. Souissi, A. L. Mimi, and H. Ben Dhia, "Integrated study of surface and subsurface data for prospecting hydrogeothermal basins: case of the Maknassy basin (central Tunisia)," Hydrological Sciences Journal, vol. 52, no. 6, pp. 1298-1315, 2007.

[17] M. Bedir, Géodynamique des bassins sédimentaires du Sahel du Mahdia (Tunisie orientale), de l'Aptien à l'actuel sismostratigraphie, sismo-tectonique et structurale. [Thèse de troisième cycle], Université El Manar Tunis, Tunis, Tunisia, 1989.

[18] H. Gabtni, “Apport de la gravimétrie à l'étude des structures profondes du Sahel de Tunisie (cas de la région de KairouanSousse-Monastir)," Comptes Rendus Geoscience, vol. 337, no. 16, pp. 1409-1414, 2005.

[19] S. Khomsi, M. Bédir, and M. G. Ben Jemia, "Mise en évidence d'un nouveau front de chevauchement dans l'Atlas tunisien oriental de Tunisie par sismique réflexion. Contexte structural régional et rôle du Trias salifère," Comptes Rendus Geoscience, vol. 336, pp. 1401-1408, 2004.

[20] S. Khomsi, M. Bédir, M. Soussi, M. G. Ben Jemia, and K. Ben Ismail-Lattrache, "Mise en évidence en subsurface d'événements compressifs Éocène moyen-supérieur en Tunisie orientale (Sahel): généralité de la phase atlasique en Afrique du Nord," Comptes Rendus Geoscience, vol. 338, pp. 41-49, 2006.

[21] R. Ghribi, Etude morpho-structurale et évolution des pléochamps de contraintes du Sahel tunisien: implications géodynamiques [Ph.D. thesis], Faculté des Sciences de Sfax, Sfax, Tunisia, 2010.

[22] E. Essefi, Multidisciplinary study of Sidi El Hani Saline environment: the history and the climatic variability [M.S. thesis], Faculty of Sciences of Sfax, University of Sfax, Sfax, Tunisia, 2009.

[23] E. Essefi, J. Touir, M. A. Tagorti et al., "Modeling of the chaotic behavior of Sidi El Hani discharge playa, Tunisian Sahel: which exogenous factor commands this saline environment? The subsurface flow or the climatic variability? Oral communication," in Proceedings of the 4th International Congress Geotunis, 2009.

[24] E. Essefi, J. Touir, M. A. Tagorti, and C. Yaich, "Effect of the groundwater contribution, the climatic change, and the human induced activities on the hydrological behavior of discharge playas: a case study Sidi El Hani discharge playa, Tunisian Sahel," Arabian Journal of Geoscience, vol. 6, no. 10, pp. 39974009, 2013.

[25] E. Essefi, Wet aeolian sedimentology and sequence stratigraphy within the terrestrial in Eastern Tunisia: implications for wet aeolian sedimentology and sequence stratigraphy on Mars [Ph.D. thesis], National Engineering School of Sfax, Sfax, Tunisia, 2013.

[26] R. Chairi, "Natural and anthropic organic contribution in environment evaporitic of oriental Tunisia: Moknine's sebkha," Le JournaL de L'eau et de L'environnement, pp. 41-55, 2004.

[27] R. Chairi and Z. El Sami-Djellouli, "Characterization of organic matter deposited in the oriental zone from Moknine hypersaline environment, oriental Tunisia," Chinese Journal of Geochemistry, vol. 24, no. 4, pp. 345-351, 2005.
[28] R. Chairi, "Sedimentological study of sediment from an hypersaline system of oriental Tunisia in recent quaternary: Moknine sebkha," Quaternaire, vol. 16, no. 2, pp. 107-117, 2005.

[29] R. Chairi, S. Derenne, S. Abdeljaoued, and C. Largeau, "Sediment cores representative of contrasting environments in salt flats of the Moknine continental sabkha (Eastern Tunisia): sedimentology, bulk features of organic matter, alkane sources and alteration," Organic Geochemistry, vol. 41, no. 7, pp. 637-652, 2010.

[30] H. Ben Jmaa, Le système endoréique de Sidi Al Hani, Chrita et Mechertate: Paléoenvironnement et dynamique récente [Ph.D. thesis], Université de Tunis, Tunis, Tunisia, 2008.

[31] N. Laridhi Ouazaa, Étude minéralogique et géochimique des épisodes magmatiques mésozoïques et miocènes de la Tunisie, [Thèse d'État], Université de Tunis, Tunis, Tunisia, 1994.

[32] M. Bedir, "Tectonic and basin structuring of eastern Tunisia seismogenic sites," 2010, http://www.docstoc.com/.

[33] A. Amari and M. Bedir, "Les bassins quaternaires du sahel central de la Tunisie. Genèse et évolution des sebkhas en contexte décrochant compressif et distensif," Géodynamqiue, vol. 4, no. 1, pp. 49-65, 1989.

[34] E. Essefi, M. A. Tagorti, J. Touir, and C. Yaich, "Modeling of the chaotic behaviors at Sidi El Hani discharge playa, eastern Tunisia: contribution of the philosophy of causality to solve complex chaotic systems in geology and biology," Tunisian Journal of Medicinal Plants and Natural Products, vol. 7, pp. 116$128,2012$.

[35] E. Essefi, G. Komatsu, A. G. Fairén, H. Ben Jmaa, F. Rekhiss, and C. Yaich, "Spring mounds at Sidi El Hani saline environment, eastern Tunisia: terrestrial analog for Mars," in Proceedings of the 43rd Lunar and Planetary Science Conference, 1229 (abstract), Houston, Tex, USA, March 2012.

[36] E. Essefi, G. Komatsu, A. G. Fairén, M. A. Chan, and C. Yaich, "Alignment of fault spring mounds at El-Guetiate, Southeast Tunisia: terrestrial analogue implications for martian tectonics," in Proceedings of the 44th Lunar and Planetary Science Conference, 1229 (abstract), Houston, Tex, USA, 2013.

[37] E. Essefi, G. Komatsu, A. G. Fairén, M. A. Chan, and C. Yaich, "Groundwater influence on the aeolian sequence stratigraphy of the Mechertate-Chrita-Sidi El Hani system, Tunisian Sahel: analogies to the wet-dry aeolian sequence stratigraphy at meridiani planum, terby crater, and gale crater, Mars," Planetary and Space Science, 2013.

[38] E. Essefi, J. Touir, M. A. Tagorti, and C. Yaich, "Record of the climatic variability and the sedimentary dynamics during the last two millennia at sebkha Dkhila, eastern Tunisia," ISRN Geology, vol. 2013, Article ID 936198, 9 pages, 2013.

[39] E. Essefi, H. Ben Jmaa, J. Touir, M. A. Tagorti, and C. Yaich, "d. Record of the climatic variability and the sedimentary dynamics during the last two millennia at sebkha Souassi, eastern Tunisia," Global Change IGBP. In press.

[40] L. Langhi, Y. Zhang, A. Gartrell, J. R. Underschultz, and D. N. Dewhurst, "Fluid flow behaviour in reactivated hydrocarbon traps: assessing fluid circulation along natural complex fault systems using numerical fluid flow simulation," Journal of Geochemical Exploration, vol. 101, no. 57, 2009.

[41] H. Boussiga, I. Saïdane, H. Belayouni, M. Dogga, and M. Chekir, "Proposal for a decontamination of wastewaters produced by oilfields in Tunisia," Geo-Eco-Trop, vol. 30, no. 2, pp. 35-40, 2006.

[42] C. Delmas-Gadras, Influence des conditions physico-chimiques sur la mobilité du plomb et du zinc dans un sol et un sédiment 
en domaine routier [Ph.D. thesis], Université de Pau et des Pays De L'Adour U.F.R Sciences, 2000.

[43] P. A. Cranwell, "Lipids of aquatic sediments and sedimenting particulates," Progress in Lipid Research, vol. 21, no. 4, pp. 271308, 1982.

[44] B. P. Tissot and D. H. Welte, Petroleum Formation and Occurrence, Springer, Berlin, Germany, 2nd edition, 1984.

[45] P. Baranger and J. R. Disnar, "Non-aromatic biomarkers associated with a Palaeogene salt formation (Bresse, France)," Organic Geochemistry, vol. 13, no. 4-6, pp. 647-653, 1988.

[46] P. Baranger, J. R. Disnar, G. Farjanel, and P. Fourmont, "Confrontation de données géochimiques et optiques quantitatives et qualitatives sur la matière organique associée aux séries salifères de Bresse," Bulletin de la Societe Geologique de France, vol. 8, pp. 967-978, 1989.

[47] V. Thiel, M. Merz-Preiß, J. Reitner, and W. Michaelis, "Biomarker studies on microbial carbonates: extractable lipids of a calcifying cyanobacterial mat (Everglades, USA)," Facies, vol. 36, no. 1, pp. 163-172, 1997.

[48] G. Eglinton and R. J. Hamilton, "Leaf epicuticular waxes," Science, vol. 156, pp. 1322-1335, 1967.

[49] S. J. Schropp, F. G. Lewis, H. L. Windom, J. D. Ryan, F. D. Calder, and L. C. Burney, "Interpretation of metal concentrations in estuarine sediments of Florida using aluminum as a reference element," Estuaries, vol. 13, no. 3, pp. 227-235, 1990. 

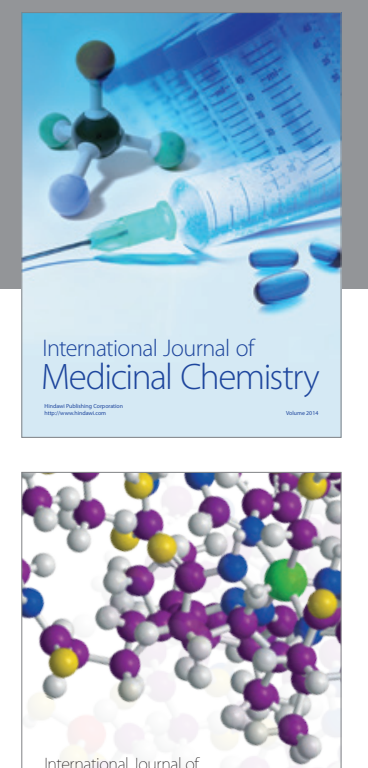

\section{Carbohydrate} Chemistry

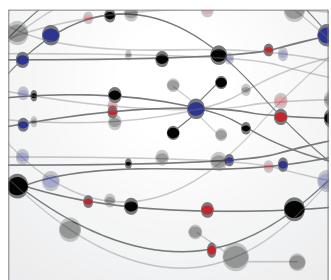

The Scientific World Journal
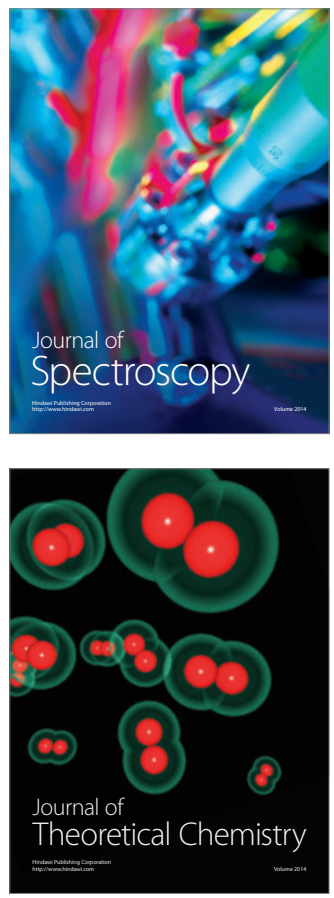
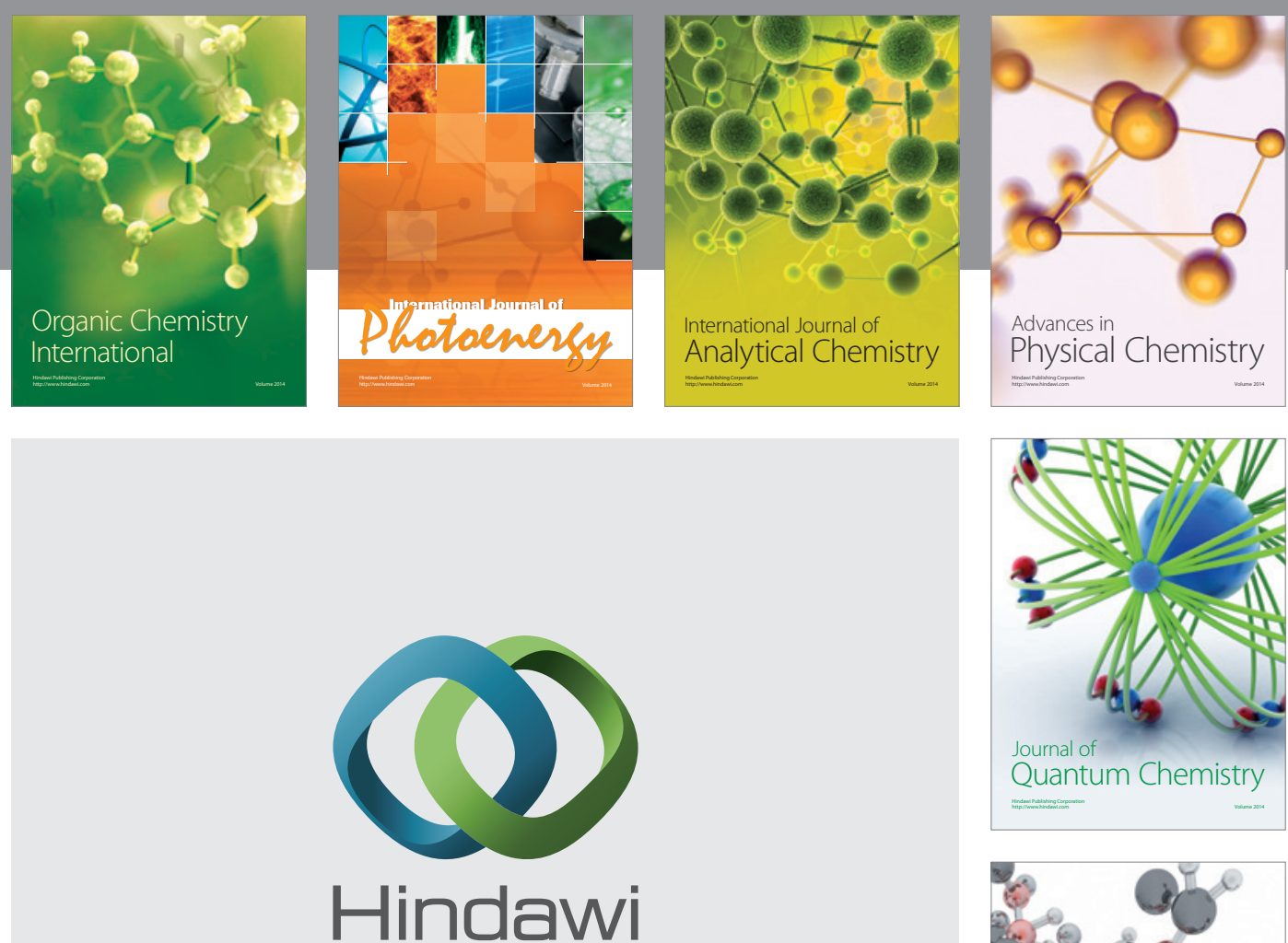

Submit your manuscripts at

http://www.hindawi.com

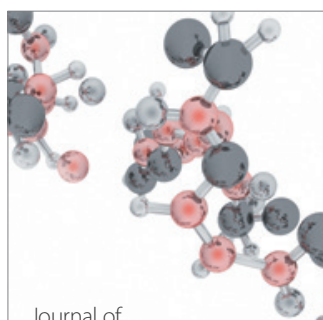

Analytical Methods

in Chemistry

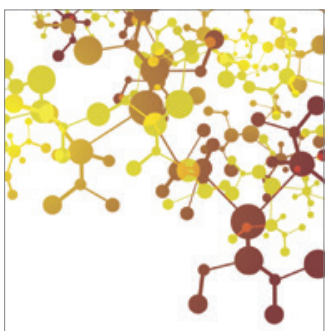

Journal of

Applied Chemistry

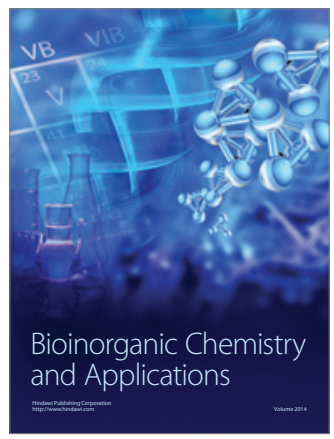

Inorganic Chemistry
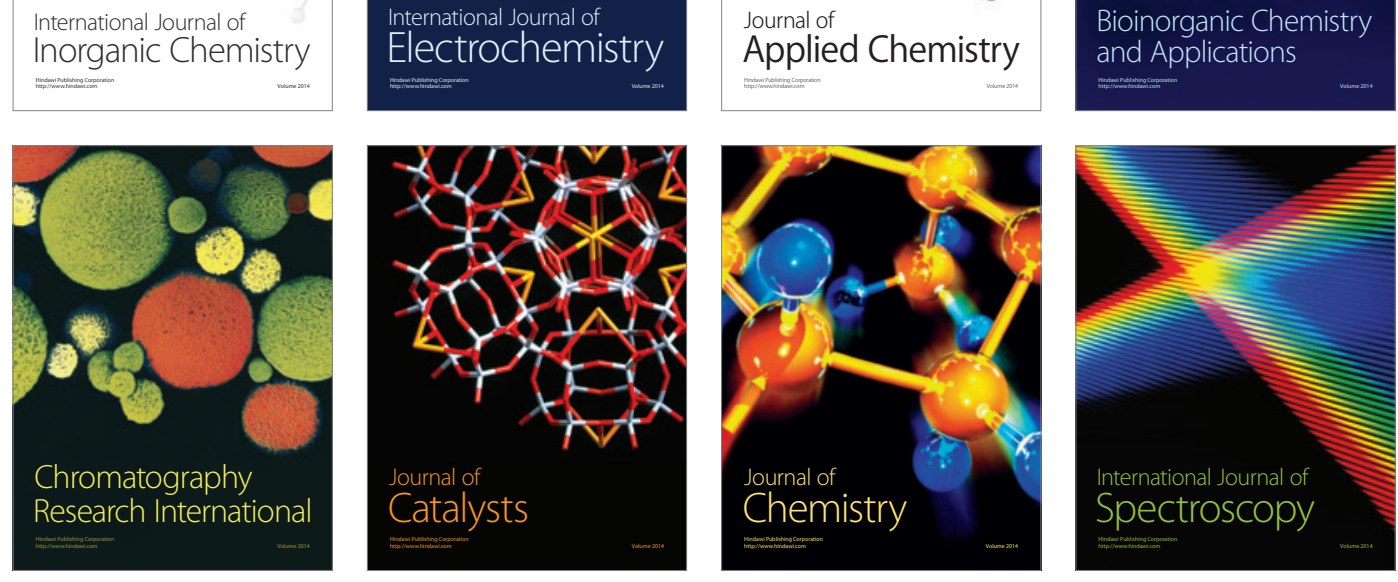